Regulation

\section{The need for tobacco regulation} N Gray

\section{No other industry is allowed the regulatory anarchy currently enjoyed by the tobacco industry}

M ichael Siegel posted the following note on the Globalink listserver on 12 February 2006. Subject: Help Get TFK to Stop Promoting Philip Morris Legislation. "Despite repeated contacts from public health folks urging them to stop, the Campaign for Tobacco-Free Kids is continuing to promote the passage of Philip Morris's chief legislative priority in the United States Congress-the socalled "effective FDA regulation of tobacco products". That is giving Philip Morris access to public health credibility that it does not deserve, and it threatens to make Philip Morris appear to be a respected advocate for effective public health policy. If you think that the Campaign for Tobacco-Free Kids, as an anti-tobacco organisation, should stop doing Philip Morris' legislative bidding for it, please go to the following link, where you can send a quick letter to the CEO of the Campaign for Tobacco-Free Kids urging them to stop playing into the hands of Philip Morris's public relations strategy."

The Campaign for Tobacco-free Kids website wants to:

- restrict tobacco advertising and promotions, especially to children

- stop illegal sales of tobacco products to children

- ban candy-flavoured cigarettes

- require changes in tobacco products, such as the reduction or elimination of harmful chemicals, to make them less harmful or less addictive

- prohibit health claims about so-called "reduced risk" products that are not scientifically proven or that would discourage current tobacco users from quitting or encourage new users to start

- require disclosure of the contents of tobacco products and tobacco industry research about the health effects of their products

- require larger and more informative health warnings on tobacco products

- prohibit terms such as "light", "mild" and "low-tar" that have misled consumers into believing that certain cigarettes are safer than others.

Further, on a podium last year I was cautioned by the editor of Tobacco Control against pleading for product regulation "because Philip Morris wants it-the black hat, white hat argument". Michael Siegel thus has some consequential support.

I completely fail to see why the achievement of such orthodox legislation would be anything but a victory for Tobacco-free Kids and for public health at large. Much of it has already been passed by countries with more advanced tobacco control policies than the United States. It may well represent a victory for Philip Morris, but that is no excuse for accepting the status quo.

The Philip Morris website ${ }^{1}$ indeed supports product regulation including the following:

- full disclosure of ingredients added to tobacco products

- authority for the Food and Drug Administration (FDA) to regulate, or ban, terms such as "light" and "low $\operatorname{tar}^{\prime \prime}$

- authority for the FDA to mandate changes in the design of tobacco products to protect the public health, including authority to remove harmful ingredients and smoke constituents.

This proposed legislation has sometimes been nicknamed the "Marlboro Monopoly Act" on the fairly reasonable grounds that Philip Morris (and the other big companies) will have less trouble complying with design restrictions than the smaller makers of generic cigarettes that are chipping away at the Marlboro market.

As a longstanding supporter of tobacco product regulation ${ }^{2-5}$-long before Philip Morris wanted it-I find this discussion a trifle bizarre. This is despite the fact that I lack complete confidence that the US FDA and other national agencies will do to the product what I think should be done to it.

To those who are hesitant to require tobacco products to be regulated, I ask: are we really to believe that cigarette design, packaging and marketing should be left to the industry? That brand trademarks are not worse than generic packaging? That levels of nitrosamines such as NNK (that vary between $35 \mathrm{ng}$ per cigarette and $325 \mathrm{ng}$ per cigarette within a single brand, in this case Marlboro in 1996) should be uncontrolled? That polyaromatic hydrocarbon yields plus lead and arsenic do not matter? That ventilated filters and all the compensatory smoking they lead to should not be outlawed? That nicotine dose delivered to the smoker should be misleadingly labelled on the packet and facilitated by ammonia technology? That the real nicotine dose should be uncontrolled? That sugars that produce acetaldehyde when burnt are acceptable? That sophisticated flavourings that appeal to children are OK?

That Philip Morris, with its leading market share, wants to keep its place is unquestioned. A stable controlled market is likely to be even better for them than the present one. While they would probably be pleased to have an FDA that would define "light" for them, they are seemingly willing to accept controls in the search for stability and predictability, where their competitive abilities will maintain their dominance.

They no doubt have a few spies on Globalink and are smiling (laughing?) as issues like this divide the tobacco control community. Nevertheless, we have to have debates if we are to ever have the policy coherence we had in the 1980s.

However, no other industry from nicotine replacement therapy to toothpaste manufacturers is allowed the regulatory anarchy enjoyed today by the tobacco industry. I think they should be regulated every which wayTobacco-free Kids are on the right train.

Tobacco Control 2006;15:145. doi: 10.1136/tc.2006.016865

Correspondence to: Nigel Gray, FRACP, Tobacco Unit, International Agency for Research on Cancer, 150 Cours Albert Thomas, 69372 Lyon cedex 08, France; nigel@uicc.org

\section{REFERENCES}

1 Philip Morris USA. FDA Regulation. Philip Morris USA. Philip Morris USA. 2002. http:// www.philipmorrisusa.com/company_news/ fda_news_list.asp (Accessed April 4 2006).

2 Gray N, Zaridze D, Robertson C, et al. Variation within global cigarette brands in tar, nicotine, and certain nitrosamines: analytic study. Tob Control 2000;9:351

3 Gray N, Zatonski W, Boyle P. Regulation of carcinogens in cigarettes. Lancet 1999:354:1036.

4 Gray N, Boyle P. The regulation of tobacco and tobacco smoke. Ann Oncol 2000;1 1:909-14.

Gray N, Boyle P. Regulation of cigarette emissions. Ann Oncol 2002;13:19-21. 